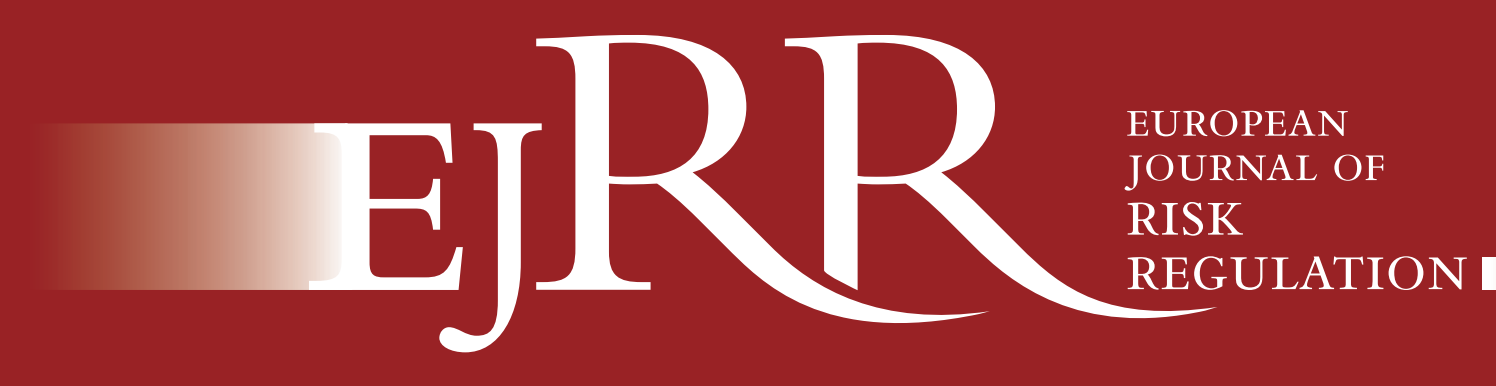

SYMPOSIUM ON CRITICAL INFRASTRUCTURES: RISK, RESPONSIBILITY AND LIABILITY

Editors: Anne van Aaken and Isabelle Wildhaber

Contributors: Kristian Cedervall Lauta, Marjolein B.A. van Asselt, Ellen Vos, Isabelle Wildhaber, Stefan Brem, Christopher Bovis, Heiko Borchert, Rainer Schweizer, Michael Faure, Anne van Aaken, Patricia Wiater, Eric Luiijf, Marieke Klaver, Peter Burgherr, Jennifer Giroux and Matteo Spada

\title{
REPORTS
}

Obesity Epidemics, the State, the Individual, and the Private in PublicPrivate Partnerships

Ana Benje

Judicial Clarifications on when Human Embryonic Stem Cells Can Be Patented

Enrico Bonadio and Angelo Maria Rovati

Edible Insects and Insect-based Products in the EU

Eugenia Costanza Laurenza and Ignacio Carreño

\section{CASE NOTES}

Enforcing EU Environmental Law against Member States: Air Pollution, National Courts and the Rule of Law Áine Ryall

Is There a Defect in the European Court's Defect Test? - Musings about Acceptable Risk

Lucas Bergkamp

Pinpointing the Appropriate Legal Basis for External Action

Graham Butler

\section{BOOK REVIEWS}

The Political Accountability of EU and US Independent Regulatory Agencies, by Miroslava Scholten, Brill Gary J. Edles

Nudge and the Law: A European Perspective, by Alberto Alemanno and Anne-Lise Sibony (Eds), Hart Publishing Fabrizio Esposito 


\title{
$9^{\text {th }}$ European Food and Feed Law Conference
}

\section{Food Law 2020 - Satisfying Comsumers' Expectations}

\author{
Thursday and Friday, 22 and 23 October 2015 | Amsterdam
}

\section{The Basis - Safe Food \\ - Better Food Control - Revision of \\ Regulation 882/2004 \\ - The Commission's Refit Programme for the food sector \\ - Safety evaluation - a task for the industry \\ - Quality Management in the Food Chain}

II. Regulated Voluntary Information

- Update on Nutrition and Health Claims A valuable marketing tool?

- Organic Food

- Claims on properties - Free-off, Vegetarian, Natural \& Co

III. Private Standards and Codes of Conduct

- Codes of conduct for retail,TV

- Fair Trade

- Regional products and geographical designations

- Certification of Environmental Claims
SPEAKERS (among others)

- Carmen GARAU, Head of Unit 5 Enforcement, Directorate-General Health and Consumers (DG SANCO), European Commission, Brussels ( $t b c)$

- Andreas MEISTERERNST, Meisterernst Rechtsanwälte, PartG mbB

- Bernd VAN DER MEULEN, Professor of Law and Governance, Wageningen University, The Netherlands

- Cassio MOREIRA, Head for Standards and Certification at the Market, WWF-International

- Karin VERZIJDEN, Attorney at law, Axon Lawyers, Amsterdam

- Ales BARTL, Associate, Jones Day, Brussels

- Dr. Tobias TEUFER, Krohn Rechtsanwälte, Hamburg

- Giorgi RUSCONI, Mondini \& Rusconi Studio Legale, Rome

- Izabela TANSKA, Partner at Food Compliance International

- Andreas KADI, SRA Consulting,Vienna
PARTICIPATION FEE: Regular fee: $€$ 995,-^ Reduced fee for full-time academics: $€ 745$,-`
EFFL subscribers receive a $10 \%$ discount.

*VAT added if applicable

\section{+++ UPCOMING EVENTS + + + UPCOMING EVENTS + + +}

\section{EFFL SEMINAR}

\section{Origin Labelling: A $360^{\circ}$ review}

\section{DECEMBER 2015, BRUSSELS}

\section{Topics:}

- When and how to label the origin: Overview of the applicable rules

- Interpretation issues - Guidelines from the European Commission

- How to determine the country of origin: Understanding the Customs Code

- The impact of customs tariffs on the country of origin - concrete examples

- Comparative study: Origin labelling and misleading information Overview of relevant case law within Europe

- Possible remedies: Protected designations and collective trademarks
SPEAKERS (among others):

- Aude Mahy, Senior Associate Commercial \& Food Law, Loyens \& Loeff, Brussels

- Gilles Boin, Partner, Product Law Firm, Paris

- Andreas Natterer, Partner, Schönherr Rechtsanwälte,Vienna

- Martin Dræbye Gantzhorn, Partner, Horten, Copenhagen (tbc) 


\section{Contents}

\section{SYMPOSIUM ON CRITICAL INFRASTRUCTURES: RISK, RESPONSIBILITY AND LIABILITY}

Opening Editorial

Anne van Aaken and Isabelle Wildhaber

Regulating a Moving Nerve

On Legally Defining Critical Infrastructure

Kristian Cedervall Lauta

Some Reflections on EU Governance of Critical Infrastructure Risks

Marjolein B.A. van Asselt, Ellen Vos and Isabelle Wildhaber

Critical Infrastructure Protection from a National Perspective

Stefan Brem

Risk in Public-Private Partnerships and Critical Infrastructure

Christopher H. Bovis

It Takes Two to Tango

Public-Private Information Management to Advance Critical Infrastructure Protection

Heiko Borchert

State Duties to Protect

A Swiss Constitutional Law Perspective

Rainer J. Schweizer

Private Liability and Critical Infrastructure

Michael Faure

State Liability and Critical Infrastructure: A Comparative and Functional Analysis

Anne van Aaken and Isabelle Wildhaber

On the notion of "Partnership" in Critical Infrastructure Protection

Patricia Wiater

Governing Critical ICT: Elements that Require Attention

Eric Luiiif and Marieke Klaver

Accidents in the Energy Sector and Energy Infrastructure Attacks in the Context of Energy Security

Peter Burgherr, Jennifer Giroux and Matteo Spada

\section{REPORTS}

Food

Clean Labels and "Self-evident" and "Flagrantly Misleading" "Palm Oil-free"

Claims

Ignacio Carreño and Paolo Vergano

Edible Insects and Insect-based Products in the EU: Safety Assessments, Legal Loopholes and Business Opportunities

Eugenia Costanza Laurenza and Ignacio Carreño 
Intellectual Property

The Court of Justice of the European Union Clarifies when Human Embryonic

Stem Cells Can Be Patented

Enrico Bonadio and Angelo Maria Rovati

Lifestyle Risks

Obesity Epidemics, the State, the Individual, and the Private in Public-Private

Partnerships

Ana Benje

\section{CASE NOTES}

Enforcing EU Environmental Law against Member States: Air Pollution,

National Courts and the Rule of Law

Áine Ryall

Is There a Defect in the European Court's Defect Test? Musings about

Acceptable Risk

Lucas Bergkamp

Pinpointing the Appropriate Legal Basis for External Action

Graham Butler

\section{BOOK REVIEWS}

The Right to Regulate in International Investment Law, by Aikaterini Titi,

Nomos

Federica Cristani

Nudge and the Law: A European Perspective, by Alberto Alemanno and Anne-Lise Sibony (Eds), Hart Publishing Fabrizio Esposito

The Political Accountability of EU and US Independent Regulatory Agencies, by Miroslava Scholten, Brill

Gary J. Edles

\section{MISCELLANEOUS}

Masthead

Imprint 


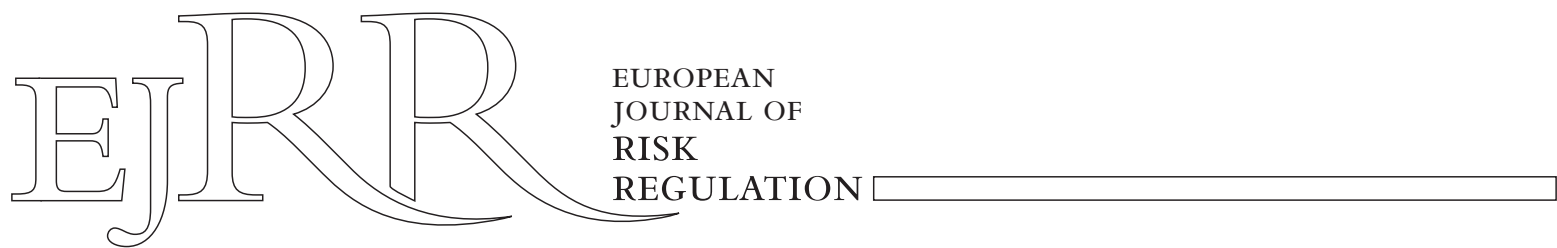

\section{EDITOR-IN-CHIEF}

Alberto Alemanno

Jean Monnet Professor of EU Law \& Risk

Regulation, HEC Paris, France

Global Clinical Professor, NYU School of Law,

New York, USA

alemanno@hec.fr

\section{ASSOCIATE EDITORS}

Pascal Cardonnel (Law)

Court of Justice of the European Union,

Luxembourg

Adam Burgess (Social Sciences)

University of Kent, United Kingdom

Enrico Bonadio (Reports)

City University London, United Kingdom

\section{EXECUTIVE EDITOR AND BOOK REVIEWS}

Cliff Wirajendi

Lexxion Publisher, Berlin

wirajendi@lexxion.eu

\section{ADVISORY BOARD}

Peter Barton Hutt

Covington \& Burling LLP, Washington DC, USA

Harvard Law School, Cambridge, USA

Carl Baudenbacher

University of St. Gallen, Switzerland

President of the EFTA Court, Luxembourg

Marco Bronckers

University of Leiden, the Netherlands

VVGB, Brussels, Belgium
Theofanis Christoforou

European Commission Legal Service, Brussels, Belgium

\section{Miguel Maduro}

European University Institute, Florence, Italy

Giandomenico Majone

European University Institute, Florence, Italy

Hans-Wolfgang Micklitz

European University Institute, Florence, Italy

Anthony Ogus

University of Manchester, United Kingdom

José Esteve Pardo

University of Barcelona, Spain

Jacques Pelkmans

Centre for European Policy Studies (CEPS),

Brussels, Belgium

Michael D. Rogers

Former Member of the Bureau of European

Policy Advisers, European Commission, Brussels,

Belgium

\section{Giorgio Sacerdoti}

Bocconi University, Milan, Italy

Former Chair of the WTO Appellate Body

Nicolas de Sadeleer

St. Louis University, Brussels, Belgium

Francis Snyder

Université Paul Cézanne, Aix-Marseille III,

France

Cass R. Sunstein

Harvard Law School, Cambridge, USA

David Vogel

Universtiy of California, Berkeley, USA

Denis Waelbroeck

Ashurst, Brussels, Belgium

College of Europe, Bruges, Belgium 
Vern Walker

Hofstra University School of Law, New York, USA

\section{EDITORIAL BOARD}

Lucas Bergkamp

Hunton \& Williams LLP, Brussels, Belgium

Susana Borrás

Copenhagen Business School, Frederiksberg, Denmark

Morten Broberg

University of Copenhagen, Denmark

Fabrizio Cafaggi

European University Institute, Florence, Italy

Dirk Detken

European Food Safety Authority (EFSA), Parma, Italy

Michael Faure

Maastricht University, the Netherlands

Mary Footer

University of Nottingham, United Kingdom

Candido Garcia Molyneux

Covington \& Burling LLP, Brussels, Belgium

Minna Heikkilä

European Chemicals Agency (ECHA), Helsinki, Finland

Sebastian Krapohl

Otto-Friedrich-University, Bamberg, Germany

Peter Kugel

VVGB, Brussels, Belgium

Shen Kui

Peking University Law School, China

Bettina Lange

University of Oxford, United Kingdom

Ragnar Lofstedt

King's Collge London, United Kingdom

Benn McGrady

Georgetown University, Washington DC, USA

Sara Poli

University of Rome 'Tor Vergata', Italy
Kai Purnhagen

Wageningen UR, the Netherlands

Erasmus University Rotterdam, the Netherlands

Reinhard Quick

VCI Liaison Office, Brussels, Belgium

Saarland University, Saarbrücken, Germany

Claudio Radaelli

Exeter University, United Kingdom

Andrea Renda

Centre for European Policy Studies (CEPS),

Brussels Belgium

LUISS Guido Carli University, Rome, Italy

Vincenzo Salvatore

Sidley Austin LLP, Brussels, Belgium

University of Insubria - Varese, Italy

Colin Scott

University College Dublin, Ireland

Sitjn Smismans

Cardiff University School of Law and Politics,

United Kingdom

Geert Van Calster

University of Leuven, Belgium

DLA Piper, Brussels, Belgium

Ellen Vos

Maastricht University, the Netherlands

Jonathan Wiener

Duke University School of Law, Durham, USA

\section{CORRESPONDENTS}

\section{Biotechnology}

Justo Corti Varela

Universidad CEU San Pablo, Madrid, Spain

Maria Weimer

University of Amsterdam, the Netherlands

Eugenia Laurenza

FratiniVergano - European Lawyers, Brussels, Belgium

\section{Food}

Ignacio Carreño

FratiniVergano - European Lawyers, Brussels,

Belgium 
Stéphanie Mahieu

Court of Justice of the European Union,

Luxembourg

\section{Intellectual Property}

Enrico Bonadio

City University London, United Kingdom

\section{Lifestyle Risks}

Jean-Patrick Villeneuve

Swiss Graduate School of Public Administration, Lausanne, Swizerland

Simon Planzer

University of St. Gallen, Switzerland

\section{Nanotechnology}

Joel D'Silva

European Association of Chemical Distributors

(FECC), Brussels, Belgium

\section{Pharmaceuticals}

Alessandro Spina

European Medicines Agency (EMA), London, United Kingdom
Anna Pavlou

Sidley Austin LLP, Brussels, Belgium

\section{Regulatory Impact Assessment}

Lorenzo Allio

Independent Policy Analyst and Consultant, Lugano, Switzerland

Jacopo Torriti

University of Reading, United Kingdom

\section{Risk Communication}

Sweta Chakraborty

Institute on Science for Global Policy, USA

\section{Trade, Investment and Risk}

Alessandra Arcuri

Erasmus University Rotterdam, the Netherlands

Alexia Herwig

University of Antwerp, Belgium

Lukasz Gruszczynski

Institute of Law Studies - Polish Academy of Sciences, Warsaw, Poland

\section{Publisher}

Lexxion Verlagsgesellschaft mbH

Güntzelstraße $63 \cdot 10717$ Berlin · Germany

Phone: +49 30/81 45 06-o - Fax: +49 30/81 45 06-22

www.lexxion.de

\section{Typeset}

Automatic typesetting by metiTEC-software

me-ti GmbH, Berlin

EJRR annual subscription* rates 2015 (4 issues)

printed version only

printed version + online edition (incl. archive) ${ }^{* *}$

online edition only (incl. archive)**

$399,00 €$

$462,00 €$

$399,00 €$

* Prices include Postage and Handling. EU Member States: VAT will be added if applicable.

** Single user online access via user name and password.

EJRR is supplied under our terms of sale and supply. Copies of our terms and conditions are available upon request. Lexxion Verlagsgesellschaft mbH. VAT Reg.No. DE 209981990.

For further information please contact

info@lexxion.de

Tel.: +49 30/81 45 o6-o · Fax: +49 30/81 45 o6-22

\section{Contributions}

are welcome and should be submitted according to the EJRR author guidelines. Any such contribution is accepted on the understanding that the author is responsible for the opinions expressed in it. More informations available at www.lexxion.eu/ejrr.

\section{Photocopying}

All rights reserved. No part of this journal may be reproduced in any form whatsoever, e.g. by photo print, microfilm, or any other means, without prior permission of the publisher. This journal was carefully produced in all its parts. Nevertheless, authors, editors and publisher do not warrant the information contained therein to be free of errors. Readers are advised to keep in mind that statements, data, illustrations, procedural details or other items may inadvertently be inaccurate.

Ownership and shareholdings pursuant to Section 7 lit. a No. 2 and Section 2 No. 6 of the Berlin Press Act: Shareholder of Lexxion Verlagsgesellschaft mbH is Dr. Wolfgang Andreae, Publisher, Berlin.

This journal may be cited as [2015] EJRR.

ISSN (Print) 1867-299X $\cdot$ ISSN (Online) 2190-8249 